\title{
Editorial
}

\section{For the end of brand balderdash - and the beginning of a real future}

Despite all that has been written about branding, despite all the conferences, speeches, industry articles, magazines and journals with 'brand' in their names, there is still massive confusion as to what a brand is, what you can genuinely expect from it, and how to make it more profitable.

This paper aims to demonstrate first that there is confusion, so that secondly we can finally agree it is unproductive and unnecessary, and finally get the discipline moving forward in a more orderly and intellectually productive fashion. It also aims to resolve some of that confusion, with the understanding that genuine resolution will require much more than this short article.

\section{TURF WARS CONTINUE, MASSIVE CONFUSION RESULTS}

We can argue among ourselves about why this confusion exists. Writing in Marketing Management, marketing professor Don E. Schultz ${ }^{1}$ partly blames our 'lack of viable brand knowledge' on 'the lack of cohesion in the exploration of brands and branding'. In other words, we agree to disagree, and that is that.

I agree with Schultz but see the situation he describes as the symptom rather than the cause. The root of the problem is that branding is the subject of an economic turf battle. Brands mean big bucks, and whoever is an expert on the subject stands to elbow a lot of other people out of the way in pursuit of the pay-off.

\section{The ad wars}

At the one extreme, there are the advertising types, whose value has declined with the rise of holistic branding approaches. In a desperate stab at credibility, they - particularly in their large, conglomerated forms claim an exaggerated, even magical creativity that then leads to all sorts of authority over branding by extension.

For example, WPP promotes 'The Brand Union' (http://www.wpp directory.com/company.jsp?company_ $\mathrm{id}=246)$. This 'union' includes not only powerhouse Enterprise IG (which apparently is not powerful enough to handle the job) but others including Addison Corporate Marketing, BDG McColl, BDG Workplace, BPRI, Coley Porter Bell, Dovetail, and many others.

Let us look at the list of services 'The Brand Union' provides under the branding umbrella. For its part, Enterprise IG is 'one of the world's leading brand and identity consultancies', so with it we have brand and identity, and they are both apparently the same as (or close to) branding. The other companies 'provide a wide range of services including strategic marketing, specialist research, corporate marketing and environmental design'.

So if I need branding but not strategic marketing, I call Enterprise IG? Or how about strategic marketing without being a brand?

There is more. The customer can also choose from: 'corporate brand consulting', 'corporate reputation re- 
search and tracking', 'brand analytics', 'consumer brand consulting and packaging', 'environmental and retail design', 'workplace design', 'brand training', 'internal marketing', and so on. Are you confused yet?

\section{The management gurus}

At the other extreme, there are management gurus who say their management genius is what it is all about. For example, McKinsey (mckinsey.com), 'a management consulting firm advising the top management of leading companies' yields many 'hits' when you type 'branding' into its search engine.

On the first such 'hit' (http://www.mckinsey.com/practices /marketing/casestudies/branding.asp), I learned that the company helped a 'consumer durables manufacturer' who sought to 'leverage its core brand and enable it to sell equipment at lower prices through the mass channel, without damaging its reputation'. OK, so brand is sort of like reputation right? And there is a 'core brand' that relates to 'equipment' and a 'mass channel'. This does not sound at all creative. Yet, apparently, the strategy worked as it 'generated US\$200m in incremental sales, as the primary mass channel partner tripled its product offerings'. What?

If you read the whole thing, it gets no more comprehensible. Look on the lower left of the screen to see a host of other case studies (or maybe case study categories) that cover such topics within branding as 'customer insights', 'customer loyalty', 'customer relationship management', 'marketing organisation and capability building', 'marketing spending effec- tiveness', 'marketing strategy', 'pricing' and 'sales and channel management'.

Can I get 'brand analytics' at McKinsey? No? Maybe I'll just settle for 'marketing spending effectiveness' instead.

\section{The brand consultants}

In the middle of this tug-of-war there are brand consultants. This group tries to balance image-building activities with business and organisational imperatives. But often it is unclear what they actually can do.

For example, BrandSolutions, Inc. tells visitors to its home page (www.brand.com) that 'Branding the careful selection and use of trademarks, images, and messages - is the most powerful tool in the commercial world'. OK - that was the image part.

The site goes on: 'BrandSolutions doesn't build brands based on hype or exaggeration; we build 'Trustmarks', brands based on shared values and ethics. BrandSolutions specializes in creating strategic 'brand solutions' designed to increase stock price and company valuation.' Just in case you missed it, those were the organisational and business parts.

A discussion of brand-oriented publications could take us further along this road, but you get the idea.

\section{WHERE DOES THAT LEAVE US?}

At this moment we do not all share a single definition of brand. But we should. And that view should incorporate all the directions in which branding has evolved:

— The 'image' school of branding is 
there to get the word out. Here are the advertising, marketing, PR and other such professionals. Their job is to deliver a message to the outside world. Period.

- The 'organisational' school of branding is there to make sure that employees are committed to delivering the brand message. Here is leadership development, management training, organisational development, and so on.

- The 'business' school of branding is the machine that keeps the brand running. It is here to make sure the numbers support the brand-building messages and organisational efforts being undertaken. Here are revenue models, valuation approaches, pricing strategies, distribution channels, and so on.

If I were the leader of the free brand world, here is what I would do to fix things:

- Partner with graduate schools around the world to institutionalise the above framework. This would be done through graduate-level brand training programmes. All prospective brand professionals would pursue a dual-track educational program. Half of it would consist of general brand theory and practice. The other would consist of one of the specialisation areas above.

- Start an independent, international professional association whose mission it is to unite brand professionals in developing common standards, benchmarks and educational materials related to branding. Ideally these standards, and the debates surrounding them, would be shared freely via the internet.
- Facilitate a shared definition of branding. Mine has evolved and is now 'a set of consistent processes, aimed at a specific purpose, that define, differentiate, and add value to the organisation'. We can debate it. But we have to come up with one. The old Coca-Cola-type definition - trademark, logo, and so on - is no longer enough. And brand is not at all reducible to any other single factor.

- Develop a brand-building model that is driven by interdependence among brand professionals and that discourages turf wars. Let's face it: everyone is good at what they are good at, and nobody is good at everything. Ad people are not qualified to handle change-management initiatives. Change-management specialists have no business trying to figure out distribution strategies. And valuation specialists should keep far, far away from the logo team.

Now is the time. Branding is smart business - and businesses know it. Enormous amounts of brain power, not to mention money, have been devoted to it. In short, all the ingredients are there to harness its massive potential and build a well-defined, structured discipline. Do we have the will to build it?

(C) 2004 Dannielle Blumenthal, $\mathrm{PhD}$

\section{Dannielle Blumenthal Editorial Board}

\section{Reference}

(1) Schultz, D. E. (2003) 'So you want to be a brand guru', Marketing Management, Vol. 12, No. 2, p. 8 